\title{
Atherosclerosis is Associated Comorbidity in Patients with Chronic Obstructive Pulmonary Disease: Ultrasound Assessment of Carotid Intima Media Thickness
}

\author{
Manal R. Hafez ${ }^{1}$, Eman Sobh르, Omaima I. Abo-Elkheir², Lobna K. Sakr \\ ${ }^{1}$ Department of Chest Diseases, Faculty of Medicine for Girls, Al-Azhar University, Cairo, Egypt \\ ${ }^{2}$ Department of Community and Occupational Medicine, Faculty of Medicine for Girls, Al-Azhar University, Cairo, Egypt \\ ${ }^{3}$ Department of Radiodiagnosis, Faculty of Medicine for Girls, Al-Azhar University, Cairo, Egypt
}

\begin{abstract}
Objective: To assess atherosclerotic comorbidity in chronic obstructive pulmonary disease (COPD) patients and its relationship to COPD severity, hypoxemia, and hypercapnia.

Methods: A hospital-based observational case-control study was conducted on 86 male COPD patients, and 86 age-matched healthy subjects (non-COPD group). Carotid intima-media thickness (CIMT) was assessed by Doppler ultrasound; in addition, spirometry and arterial blood gas tests were done.

Results: CIMT was significantly increased in the COPD group compared to the non-COPD group $(0.84 \pm 0.15$ vs. $0.63 \pm 0.076, p<0.001)$. When the CIMT value of $\geq 0.8 \mathrm{~mm}$ was defined as a cutoff value for a thickened CIMT complex, $64 \%$ of COPD patients versus $8.1 \%$ of nonCOPD subjects had a thickened CIMT. COPD patients with a thickened CIMT were older and had a higher $\mathrm{PaCO}_{2}$, lower FEV $\%$, FVC, and $\mathrm{FEF}_{25-75} \%$ compared to COPD patients with a normal CIMT. Thickened CIMT in COPD patients was significantly associated with hypoxemia ( $\mathrm{p}=0.008, \mathrm{OR}=8.2)$, hypercapnia $(\mathrm{p}=0.04, \mathrm{OR}=6.2)$, and airflow limitation $(\mathrm{p}=0.11, \mathrm{OR}=2.1)$. There was no significant difference in CIMT in relation to COPD severity $(\mathrm{p}=0.83)$.
\end{abstract}

Conclusion: Atherosclerosis is prevalent in COPD patients, even in the early stages of the disease. Hypoxemia, hypercapnia, and airflow limitation are risk factors of atherosclerosis in COPD patients.

Keywords: Arterial stiffness in COPD, atherosclerosis, cardiovascular risk in COPD, carotid intima media thickness, COPD

Received Date: 18.08 .2016 Accepted Date: 19.10 .2016

DOI: $10.5152 /$ ejp.2016.63626

Corresponding Author

Eman Sobh

E-mail: emansobh2012@gmail.com

- Available online at www.eurasianjpulmonol.com 4.0 International License.

\section{INTRODUCTION}

Chronic obstructive pulmonary disease (COPD) is considered a systemic disease with various co-morbidities (1). It is well established that cardiovascular diseases (CVDs) contribute significantly to both morbidity and mortality in COPD (2). In addition, there is increasing evidence that COPD is an independent risk factor for cerebrovascular ischemic stroke and that the risk increases with severity of airflow limitation (3).

Preclinical carotid atherosclerosis, characterized by increased intima-media thickness (IMT), is an indicator of atherosclerosis burden and a CVD risk (4). It reflects the atherosclerotic involvement of the vascular structure, thereby indicating coronary artery disease, cerebrovascular disease, and peripheral arterial disease (5). Carotid atherosclerosis strongly correlates with coronary atherosclerosis (6).

The mechanism for the association of COPD with increased carotid wall IMT is not well known ( 7 , 8). It has been postulated that COPD is a disease of accelerated aging $(9,10)$. Mechanisms related to accelerate aging and cellular senescence are also considered to be involved in the pathogenesis of atherosclerosis (11). Evidence of the accelerated aging process in both COPD and atherosclerosis was confirmed by shortened leukocyte telomere lengths $(10,12)$, which may provide a mechanistic link between COPD and vascular dysfunction (2). Additionally, low-grade systemic inflammation (8), 
high smoking prevalence, a sedentary lifestyle, low forced expiratory volume in first second (FEV $)_{1}$ (13), platelet activation, hypercoagulability, and oxidative stress are possible important contributors (7, 14). Patients with COPD are subjected to hypoxia, either sustained or intermittent, during exercise or exacerbations. Chronic intermittent hypoxia is associated with hyperlipidemia, atherosclerosis, and a high cardiovascular risk; and the severity of atherosclerosis correlates with the severity of hypoxia (15). Moreover, abnormalities of the arterial wall extracellular matrix as a result of elastin degradation in the lungs (resulting in emphysema), and in the vasculature (resulting in atherosclerosis) (16) could be a possible mechanism. Among these factors, systemic inflammation was thought to be the most obvious risk factor (13).

There is increasing evidence that non-invasive imaging modalities, such as ultrasonography, may be able to detect subclinical atherosclerotic lesions (17). Carotid intima-media thickness (CIMT) measured by carotid Doppler ultrasound is an effective, reliable, and validated method for evaluating carotid atherosclerosis (18). Measurement of the CIMT by ultrasound can detect thickening of the artery wall during the initial phases of atherosclerosis before the lumens become compromised (19).

Increased IMT was connected to increased cardiovascular morbidity in patients with COPD (4). However, the clinical relevance of these observations remains unknown in patients with COPD (17). Accordingly, the aim of this study was to assess atherosclerotic comorbidity in COPD patients and its relation to COPD severity, hypoxemia, and hypercapnia.

\section{METHODS}

\section{Study Design}

This was a hospital-based observational case-control study conducted from December 2014 to January 2016.

\section{Sample and Place of Study}

The study was conducted on 172 participants [86 COPD patients and 86 non-COPD subjects (controls)]. It was carried out at the Chest Diseases Department, Al-Zahraa University Hospital, Cairo, Egypt.

\section{Selection of Subjects}

1. COPD group: The diagnosis and staging of COPD were based on the GOLD, 2014 criteria (post-bronchodilator FEV $/$ FVC $<0.7$ ) and an increase in $\mathrm{FEV}_{1}<200 \mathrm{~mL}$, or $<12 \%$ of the baseline value 20 minutes after $200 \mu \mathrm{g}$ puffs of inhaled Salbutamol (given via a metered-dose inhaler at the time of diagnosis) (20).

2. Non-COPD group: An equal number of age and sex-matched healthy volunteers with spirometric indices and arterial blood gases (ABG) parameters within the normal range and no history of chronic chest diseases.

\section{Exclusion Criteria}

Subjects with systemic hypertension, diabetes mellitus, atherosclerosis, dyslipidemia, known CVD/cerebrovascular diseases, or history of lipid lowering drugs intake were excluded from the study.

Age, smoking frequency (pack/year), and body mass index (BMI) were recorded; and all participants were subjected to the following:
1. Spirometry: Spirometry was carried out on a MEDISOFT-HYPERAIR compact + flow meter pulmonary function testing device (Medisoft, Sorinnes, Belgium). The test procedure was explained in full detail. Short-acting $\beta 2$ agonist, long-acting $\beta 2$-agonists, and sustained-release theophylline, were withheld before the test for 6, 12, and 24 hours, respectively. Heavy meals, exercise, and smoking were avoided 6 hours before the test. $\mathrm{FEV}_{1} \%$, forced vital capacity (FVC\%), $\mathrm{FEV}_{1} / \mathrm{FVC}$ ratio, and forced expiratory flow rate $25 \%-75 \%\left(\mathrm{FEF}_{25-75} \%\right)$ were measured. Spirometric indices were calculated using the best of 3 technically acceptable performances in accordance with the recommendations of the European Respiratory Society (21).

2. Arterial blood gases: $A B G$ analysis was done after a 15-minute resting period in ambient room air using a Rapid Lab 248 blood (Siemens Medical Solutions, Malvern, PA, US) gases analyzer; $\mathrm{PaO}_{2} \mathrm{mmHg}$, and $\mathrm{PaCO}_{2} \mathrm{mmHg}$ were recorded.

3. Measurements of CIMT: Carotid artery intima-media thickness was measured using ultrasound by well-trained investigators (two pulmonologists and a radiologist).

Estimation of the inter-rater reliability of measurements from the three investigators was performed. Data from ultrasound imaging of IMT, one reading per investigator, were recorded for 20 participants as a pilot test. The inter-rater (inter-observer) reliability of the measurements among the three investigators was assessed by calculating the Intraclass Correlation Coefficient (ICC) (22). Our estimated ICC was 0.882 , with a $95 \%$ Confidence Interval $(\mathrm{Cl})(0.78,0.94)$, which was considered excellent (23). Accordingly, we have evidence to support the reliability of measurements between the three investigators. The measurements of the pilot test were not included in the sample of this study.

Intima-media thickness was measured by ultrasonography using the longitudinal axis of both common carotid arteries (CCA) while the patient lying in the supine position with neck rotated to the opposite side of examination. The exams were performed using a B-mode ultrasound with a Sonoscape A8 (Medical Systems, Shenzhen, China), using a 10-12 MHz linear transducer. Optimal B-mode settings of gain, depth of placement, and compression were individually adjusted for each vessel to enhance arterial wall structures and image quality, in accordance with IMT measurement protocols (24). The normal thickness of the intima-media complex measured in the B-mode [from the lumen-intima interface (the first hyperechoic line) to the media-adventitia interface (the second hyperechoic line)] was 0.5$0.6 \mathrm{~mm}$ and increased somewhat with age (Figure 1) (25). Bilateral carotid arteries were evaluated and CCA-IMT was measured. At least three IMT measurements were obtained for each near and far wall. Mean CIMT values from the far walls of both the right and left CCAs (mean-mean) were reported $(26,27)$. CIMT values $\geq 0.8 \mathrm{~mm}$ were defined as the cut-off value for a thickened CIM complex (Figure 2) (8).

\section{Ethical Considerations}

This study was approved by the ethical review committee of the Faculty of Medicine for Girls Al-Azhar University, Cairo, Egypt. Participation was voluntary; an informed consent was obtained from each study participant. Each participant had the right to refuse participation or withdraw from the study at any point without giving any reasons and without affecting their rights of medical care. Also, data were anonymous and coded to assure confidentiality of participants. 


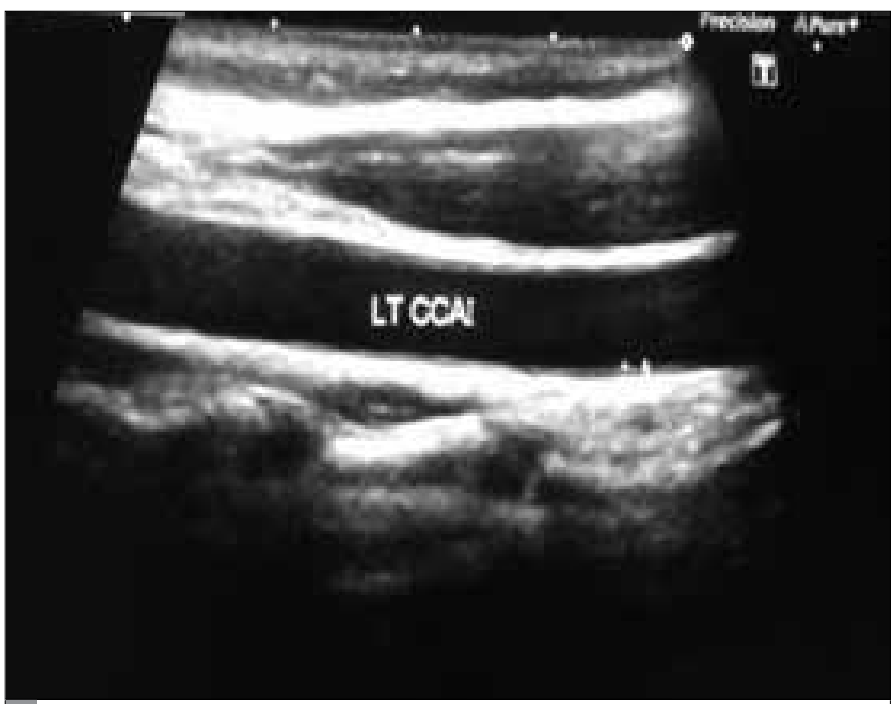

Figure 1. Normal CIMT. Normal carotid intima media thickness $(0.6 \mathrm{~mm})$

LT CCA: Left common carotid artery; CIMT: carotid intima-media thickness

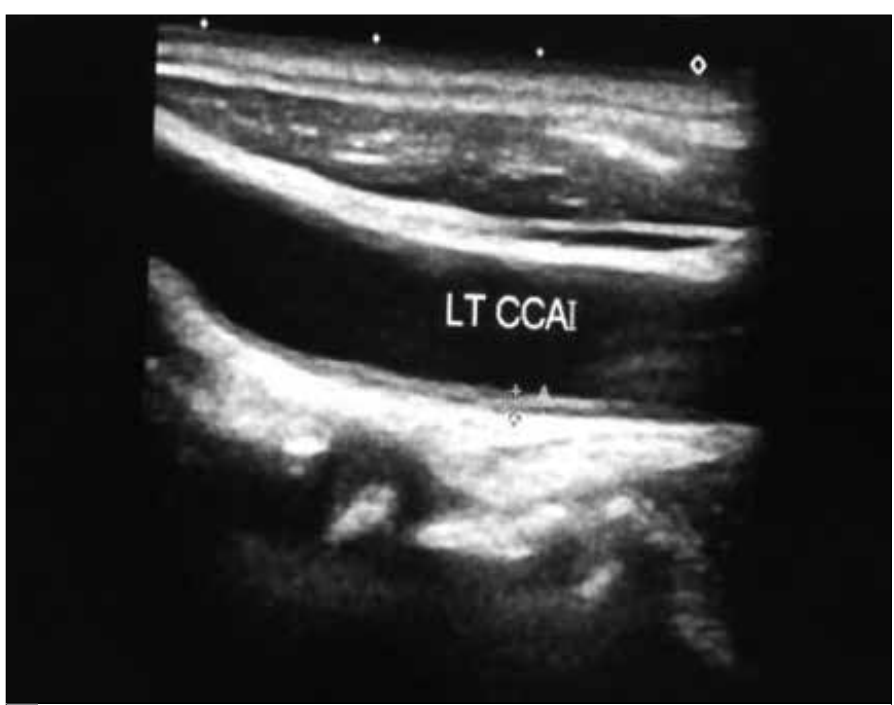

Figure 2. Thickened CIMT. Increased carotid intima media thickness $(1.4 \mathrm{~mm})$

LT CCA: Left common carotid artery; CIMT: carotid intima-media thickness

\section{Statistical Analysis}

Data was statistically analyzed by the Statistical Package for Social Science (SPSS) program version 17.0 (SPSS Inc.; Chicago, USA). Descriptive analysis was done for each item and the results were expressed as mean \pm SD for quantitative continuous variables, and as percentages for qualitative (categorical and nominal) variables. The studied COPD cases were categorized into two groups based on their CIMT. Comparisons to assess the difference between the groups used the Chi-square $\left(X^{2}\right)$ test for qualitative data and the Student's t-test for quantitative data (the Shapiro-Wilk test was used for testing normality of the studied variables). The odds ratio was calculated to measure the association between the risk factors and the outcome. Multivariate logistic regression analysis was used to identify the most relevant risk factors affecting thickness of the carotid intima among patients with COPD. The strength of relevance between the risk factors and the outcome was determined according to the value of the Beta co-
Table 1. Comparison between COPD group and non-COPD group regarding personal characteristics, spirometric indices, and carotid artery intima-media thickness

\begin{tabular}{|c|c|c|c|}
\hline $\begin{array}{l}\text { Groups } \\
\text { Items }\end{array}$ & $\begin{array}{c}\text { COPD group } \\
\text { No. }=86\end{array}$ & $\begin{array}{c}\text { Non-COPD group } \\
\text { No. }=86\end{array}$ & $\begin{array}{c}\text { Sig. test } \\
\mathbf{p}\end{array}$ \\
\hline $\begin{array}{l}\text { Carotid IM thickness } \\
\text { Normal } \\
\text { Thickened }(\geq 0.8 \mathrm{~mm})\end{array}$ & $\begin{array}{l}31(36.0 \%) \\
55(64.0 \%)\end{array}$ & $\begin{array}{c}79(91.9 \%) \\
7(8.1 \%)\end{array}$ & $\begin{array}{l}\chi^{2}=58.1 \\
p<0.001^{*}\end{array}$ \\
\hline $\begin{array}{l}\text { CIMT/mm } \\
\text { Mean } \pm \text { SD }\end{array}$ & $0.84 \pm 0.15$ & $0.63 \pm 0.076$ & $\begin{array}{c}\text { t-test }=11.0 \\
p<0.001^{*}\end{array}$ \\
\hline $\begin{array}{l}\text { Age/year } \\
\text { Mean } \pm \text { SD }\end{array}$ & $61.9 \pm 9.2$ & $60.3 \pm 8.9$ & $\begin{array}{c}\text { t-test }=1.2 \\
p=0.23\end{array}$ \\
\hline $\begin{array}{r}\mathrm{BMI} / \mathrm{kg} / \mathrm{m}^{2} \\
\text { Mean } \pm \mathrm{SD}\end{array}$ & $28.5 \pm 5.11$ & $29.1 \pm 3.1$ & $\begin{array}{c}\text { t-test }=0.88 \\
p=0.38\end{array}$ \\
\hline $\begin{array}{l}\text { Smoking status } \\
\text { Non smoker } \\
\text { Smoker }\end{array}$ & $\begin{array}{c}6(7.0 \%) \\
80(93.0 \%)\end{array}$ & $\begin{array}{l}57(66.3 \%) \\
29(33.7 \%)\end{array}$ & $\begin{array}{l}\chi^{2}=65.1 \\
p<0.001^{*}\end{array}$ \\
\hline $\begin{array}{l}\text { Smoking (pack/year) } \\
\qquad \text { Mean } \pm \text { SD }\end{array}$ & $40.0 \pm 5.5$ & $25.4 \pm 9.6$ & $\begin{array}{c}\text { t-test }=11.7 \\
p<0.001^{*}\end{array}$ \\
\hline $\begin{array}{l}\mathrm{FEV}_{1} / \mathrm{FVC} \\
\text { Mean } \pm \mathrm{SD}\end{array}$ & $58.2 \pm 13.72$ & $83.5 \pm 10.3$ & $\begin{array}{c}\text { t-test }=13.6 \\
p<0.001^{*}\end{array}$ \\
\hline $\begin{array}{l}\mathrm{FEV}_{1} \% \\
\quad \text { Mean } \pm \mathrm{SD}\end{array}$ & $46.3 \pm 19.19$ & $92.6 \pm 15.9$ & $\begin{array}{c}\text { t-test }=17.4 \\
p<0.001^{*}\end{array}$ \\
\hline $\begin{array}{l}\text { FVC\% } \\
\qquad \text { Mean } \pm \text { SD }\end{array}$ & $61.5 \pm 19.2$ & $94.3 \pm 10.9$ & $\begin{array}{c}\text { t-test }=13.7 \\
p<0.001^{*}\end{array}$ \\
\hline $\begin{array}{l}\mathrm{FEF}_{25-75} \% \\
\quad \text { Mean } \pm \mathrm{SD}\end{array}$ & $34.2 \pm 17.8$ & $71.4 \pm 7.4$ & $\begin{array}{c}\text { t-test }=17.9 \\
p<0.001^{*}\end{array}$ \\
\hline
\end{tabular}

* Significant $\mathrm{p}$-value

BMI: Body Mass Index; CIMT: carotid intima-media thickness; COPD; chronic obstructive pulmonary disease; $\mathrm{FEF}_{25-75} \%$ : forced expiratory flow rate $25 \%-75 \%$; $\mathrm{FEV}_{1}$ : forced expiratory volume in first second; FVC: forced vital capacity; SD: standard deviation

efficient (B), and significance according to the Wald Chi-square test; also, the Odds ratio (OR) was calculated. Analysis of inter-observer reliability was made with the ICC and $\mathrm{Cl}$ of $95 \%$. Agreement levels were classified as poor $(<0.20)$, fair $(0.21-0.40)$, moderate $(0.41-0.60)$, good (0.61-0.80), and excellent (>0.80) (23). Statistical significance was considered at a $\mathrm{p}$-value $<0.05$ (with a confidence limit at $95 \%$ ). Results are presented in tables and figures.

\section{RESULTS}

Table 1 shows that the smoking frequency (pack/year) was significantly higher $(p=0.001)$, while spirometric-indices were significantly lower in the COPD group than the non-COPD group. CIMT was signifi- 
Table 2. Comparison between COPD with normal CIMT and COPD with thickened CIMT group in regards to personal characteristics, spirometric indices and carotid thickness

\begin{tabular}{|c|c|c|c|}
\hline $\begin{array}{l}\text { Groups } \\
\text { Items }\end{array}$ & $\begin{array}{l}\text { COPD with } \\
\text { Normal CIMT } \\
\text { No. }=31\end{array}$ & $\begin{array}{l}\text { COPD with } \\
\text { Thickened CIMT } \\
\text { No. }=55\end{array}$ & $\underset{\mathbf{p}}{\text { Sig. test }}$ \\
\hline $\begin{array}{l}\text { CIMT } \\
\quad \text { Mean } \pm S D\end{array}$ & $0.67 \pm 0.05$ & $0.94 \pm 0.09$ & $\begin{array}{c}\text { t-test }=13.4 \\
p<0.001^{*}\end{array}$ \\
\hline $\begin{array}{l}\text { Age/years } \\
\text { Mean } \pm \text { SD }\end{array}$ & $58.1 \pm 7.6$ & $63.3 \pm 10.6$ & $\begin{array}{c}t=2.4 \\
p=0.02^{*}\end{array}$ \\
\hline $\begin{array}{l}\text { BMl kg/m² } \\
\quad \text { Mean } \pm S D\end{array}$ & $27.9 \pm 4.6$ & $28.9 \pm 5.4$ & $\begin{array}{l}t=0.79 \\
p=0.37\end{array}$ \\
\hline $\begin{array}{l}\text { Smoking status } \\
\text { Non smoker } \\
\text { Smoker }\end{array}$ & $\begin{array}{c}2(6.5 \%) \\
29(93.5 \%)\end{array}$ & $\begin{array}{c}4(7.3 \%) \\
51(92.7 \%)\end{array}$ & $\begin{array}{c}\chi^{2}=0.02 \\
p=0.88 \\
O R=0.87 \\
(0.152-5.1)\end{array}$ \\
\hline $\begin{array}{l}\text { Smoking (pack/year) } \\
\text { Mean } \pm \text { SD }\end{array}$ & $41.1 \pm 31.3$ & $39.4 \pm 21.6$ & $\begin{array}{c}\text { t-test }=0.26 \\
p=0.78\end{array}$ \\
\hline $\begin{array}{l}\text { COPD duration/years } \\
\text { Mean } \pm \text { SD }\end{array}$ & $11.7 \pm 8.1$ & $13.3 \pm 8.7$ & $\begin{array}{c}\text { t-test }=0.82 \\
p=0.41\end{array}$ \\
\hline $\begin{array}{l}\text { Hypoxemia } \\
\text { No } \\
\text { Yes }\end{array}$ & $\begin{array}{l}10(32.3 \%) \\
21(67.7 \%)\end{array}$ & $\begin{array}{c}3(5.5 \%) \\
52(94.5 \%)\end{array}$ & $\begin{array}{c}\chi^{2}=11.1 \\
\mathrm{p}=0.001^{*} \\
\mathrm{OR}=8.2 \\
(2.1-33.0)\end{array}$ \\
\hline $\begin{array}{l}\mathrm{PaO}_{2} \mathrm{mmHg} \\
\text { Mean } \pm \mathrm{SD}\end{array}$ & $75.8 \pm 8.7$ & $64.9 \pm 11.2$ & $\begin{array}{c}t=4.7 \\
p<0.001^{*}\end{array}$ \\
\hline $\begin{array}{l}\text { Hypercapnia } \\
\text { No } \\
\text { Yes }\end{array}$ & $\begin{array}{c}28(90.3 \%) \\
3(9.7 \%)\end{array}$ & $\begin{array}{l}33(60.0 \%) \\
22(40.0 \%)\end{array}$ & $\begin{array}{c}\chi^{2}=8.8 \\
p=0.003^{*} \\
O R=6.2 \\
(1.68-22.9)\end{array}$ \\
\hline $\begin{array}{r}\mathrm{PaCO}_{2} \mathrm{mmHg} \\
\text { Mean } \pm \mathrm{SD}\end{array}$ & $39.9 \pm 6.8$ & $44.4 \pm 10.7$ & $\begin{array}{l}\text { t-test }=2.1 \\
p=0.04^{*}\end{array}$ \\
\hline $\begin{array}{l}\text { COPD Severity } \\
\text { Mild - moderate } \\
\text { Severe -very severe }\end{array}$ & $\begin{array}{l}15(48.4 \%) \\
16(51.6 \%)\end{array}$ & $\begin{array}{l}17(30.9 \%) \\
38(69.1 \%)\end{array}$ & $\begin{array}{c}\chi^{2}=2.6 \\
p=0.11 \\
O R=2.1 \\
(0.846-5.19)\end{array}$ \\
\hline $\begin{array}{l}\mathrm{FEV}_{1} \% \\
\quad \text { Mean } \pm \mathrm{SD}\end{array}$ & $53.4 \pm 17.4$ & $42.4 \pm 19.2$ & $\begin{array}{c}\text { t-test }=2.6 \\
p=0.01^{*}\end{array}$ \\
\hline $\begin{array}{l}\text { FEV FVC } \\
\text { Mean } \pm \text { SD }\end{array}$ & $57.5 \pm 13.8$ & $58.6 \pm 13.8$ & $\begin{array}{c}\text { t-test }=0.37 \\
p=0.7\end{array}$ \\
\hline $\begin{array}{l}\text { FVC } \% \\
\qquad \text { Mean } \pm \text { SD }\end{array}$ & $73.8 \pm 18.8$ & $54.5 \pm 15.6$ & $\begin{array}{l}\text { t-test }=5.1 \\
p<0.001^{*}\end{array}$ \\
\hline $\begin{array}{l}\mathrm{FEF}_{25-75} \% \\
\quad \text { Mean } \pm \mathrm{SD}\end{array}$ & $39.9 \pm 21.8$ & $31.0 \pm 14.4$ & $\begin{array}{c}\text { t-test }=2.3 \\
p=0.02^{*}\end{array}$ \\
\hline
\end{tabular}

* Significant p-value

BMl: Body Mass Index; CIMT: carotid intima-media thickness; COPD: chronic obstructive pulmonary disease; $\mathrm{FEF}_{25-75} \%$ : forced expiratory flow rate $25 \%-75 \%$; $\mathrm{FEV}_{1}$ : forced expiratory volume in first second; FVC: forced vital capacity; $\mathrm{mmHg}$ : millimeter mercury $\mathrm{PaCO}_{2}$ : partial pressure of carbon dioxide; $\mathrm{PaO}_{2}$ : partial oxygen pressure; $\mathrm{SD}$ : standard deviation
Table 3. Comparison of CIMT in COPD patients according to hypoxemia, hypercapnia, and COPD severity

\begin{tabular}{|l|c|c|}
\hline Items & $\begin{array}{c}\text { CIMT } \\
\text { Mean } \pm \text { SD }\end{array}$ & $\begin{array}{c}\text { Sig. test } \\
\mathbf{p}\end{array}$ \\
\hline Hypoxemia & & \\
No (No.=13) & $0.74 \pm 0.17$ & t-test $=2.7$ \\
Yes (No.=73) & $0.86 \pm 0.14$ & $\mathrm{p}=0.008^{*}$ \\
Hypercapnia & & \\
No (No.=61) & $0.82 \pm 0.15$ & $\mathrm{t}$-test $=2.0$ \\
Yes (No. =25) & $0.89 \pm 0.13$ & $\mathrm{p}=0.04^{*}$ \\
COPD Severity & & \\
Mild - moderate (No.=32) & $0.83 . \pm 0.15$ & $\mathrm{t}$-test=0.042 \\
Severe - very severe (No.=54) & $0.84 \pm 0.16$ & $\mathrm{p}=0.83$ \\
\hline
\end{tabular}

*Significant p-value

CIMT: carotid intima-media thickness; COPD: chronic obstructive pulmonary disease; SD: standard deviation

cantly increased in the COPD group compared to the control group $(p<0.001)$. Additionally, $64 \%$ of COPD patients and $8.1 \%$ of non-COPD controls had a thickened CIM ( $p<0.001)$. Table 2 shows that age and $\mathrm{PaCO}_{2}$ were significantly higher while $\mathrm{PaO}_{2}, \mathrm{FEV}_{1} \%, \mathrm{FVC}$, and $\mathrm{FEF}_{25-}$ ${ }_{75} \%$ were significantly lower in COPD patients with a thickened CIMT compared to COPD patients with a normal CIMT. There was no significant difference between both groups regarding BMI, smoking history $(\mathrm{OR}<1)$, smoking frequency (pack/year), and airflow limitation $(\mathrm{OR}=2.195 . \% \mathrm{Cl}$ 0.846-5.19). Thickened CIMT in COPD patients was significantly associated with hypoxemia $(\mathrm{OR}=8.2,95 \% \mathrm{Cl}, 2.1-33.0)$ and hypercapnia $(\mathrm{OR}=6.2,95 \% \mathrm{Cl}, 1.68-22.9)$. These findings indicate that COPD patients with hypoxemia had an 8-fold increased risk for developing atherosclerosis while COPD patients with hypercapnia had a 6-fold increased risk of developing atherosclerosis. Table 3 shows that CIMT was significantly increased in COPD patients with hypoxemia compared to COPD patients without hypoxemia $(p=0.008)$, and in COPD patients with hypercapnia compared to COPD patients without hypercapnia $(p=0.04)$. No significant difference in CIMT was found among different stages of COPD severity $(p=0.83)$. The Table 4 multivariate logistic regression analysis revealed that the most significant risk factors relevant to the thickened carotid intima among patients with COPD were age $(B=0.139)$ followed by $\mathrm{PaO}_{2}(B=-0.1)$. Both $\mathrm{PaCO}_{2}$ and $\mathrm{FEV}_{1} \%$ ( $\mathrm{B}=0.056$ and -0.016 , respectively) were insignificantly relevant to a thickened CIMT. Moreover, smoking frequency (pack/year) was not relevant to a thickened carotid intima $(B=0.000)$.

\section{DISCUSSION}

There is increasing awareness that the inflammatory state associated with COPD is not confined to the lungs, but also involves the whole circulation system and can affect extra-pulmonary organs (28). These comorbidities account for more than $50 \%$ of COPD-related health costs (29). Thus, it is important to evaluate COPD patients for these comorbidities.

In the current study, $64 \%$ of COPD patients (versus $8.1 \%$ of healthy controls) had a thickened CIMT. In the same context, other investigators reported a higher prevalence of thickened CIMT in patients with COPD than the control group $(8,17,30,31)$, Furthermore, Chindhi 
Table 4. Multivariate logistic regression of risk factors for carotid intima thickening among patients with COPD

\begin{tabular}{|c|c|c|c|c|c|c|c|}
\hline \multirow{2}{*}{$\begin{array}{l}\text { Independent } \\
\text { variables }\end{array}$} & \multirow{2}{*}{$\begin{array}{l}\text { Beta coefficient } \\
\text { (B) }\end{array}$} & \multirow[b]{2}{*}{ S.E. } & \multirow[b]{2}{*}{ Wald test } & \multirow[b]{2}{*}{$p$} & \multirow[b]{2}{*}{$\operatorname{Exp}(B)$} & \multicolumn{2}{|c|}{ 95\% C.I. for EXP(B) } \\
\hline & & & & & & Lower & Upper \\
\hline Age/years & 0.139 & 0.042 & 10.852 & $0.001^{*}$ & 1.149 & 1.058 & 1.249 \\
\hline $\mathrm{PaO}_{2} \mathrm{mmHg}$ & -0.100 & 0.031 & 10.166 & $0.001^{*}$ & 0.905 & 0.851 & 0.962 \\
\hline $\mathrm{PaCO}_{2} \mathrm{mmHg}$ & 0.056 & 0.053 & 1.099 & 0.294 & 1.057 & 0.953 & 1.173 \\
\hline Smoking (pack/year) & 0.000 & 0.001 & 1.860 & 0.173 & 0.999 & 0.998 & 1.000 \\
\hline Constant & -1.663 & 4.810 & 0.119 & 0.730 & 0.190 & & \\
\hline \multicolumn{8}{|c|}{$\begin{array}{l}\text { *Significant } \mathrm{p} \text {-value } \\
\text { C.I.: confidence interval; } \mathrm{FEV}_{1} \text { : Forced expiratory volume in first second; } \mathrm{mmHg} \text { : millimeter mercury; } \mathrm{PaCO}_{2} \text { : partial pressure of carbon dioxide; } \mathrm{PaO}_{2} \text { : } \text { partial } \\
\text { oxygen pressure; S.E.: standard error }\end{array}$} \\
\hline
\end{tabular}

et al. (32) documented that the prevalence of carotid plaque formation was significantly higher among COPD patients compared to the controls. Additionally, CIMT was found to be significantly higher among our study COPD patients than the controls $(0.85 \pm 0.18 \mathrm{~mm}$ vs. $0.63 \pm 0.076 \mathrm{~mm}, \mathrm{p}<0.001)$. These results coincide with the results of other studies in the literature $(4,17,33-39)$.

Although, smoking is a well-known risk factor for atherosclerosis; results of this study revealed that smoking was not relevant to an increased CIMT among the studied COPD patients both by logistic regression analysis and by estimation of risk $(\mathrm{OR}<1)($ Table 2,4$)$. Similar results were reported by other investigators (38); they found that smoking frequency (pack/year) did not differ between COPD patients with normal CIMT and those with a thickened CIMT. Two other studies reported that CIMT was significantly increased: in smoker COPD patients compared to the smoker control group (37) and in smokers with airflow limitation compared to smokers in the control group and never-smokers in the control group (40). This might be an indication of the influence of other factors leading to intimal thickening other than smoking.

This study demonstrated that $\mathrm{FEV}_{1} \%$ was significantly lower in COPD patients with a thickened CIMT compared to those with a normal CIMT; however, CIMT did not differ significantly between the mild-to-moderate and severe-to-very severe COPD patients. These findings indicate that atherosclerosis initiated in the early stages of COPD and it also suggests that airflow limitation is associated with atherosclerosis. These results are supported by many studies that reported significantly higher CIMT in COPD patients with a lower FEV $(41-45)$, and it was not significant between different COPD stages $(8,32)$. In addition, van Gestel et al. (17) documented that moderate-to-severe COPD was independently associated with increased CIMT, regardless of the smoking status. In the same context, Anthonisen et al. (46) reported that, for every $10 \%$ decrease in $\mathrm{FEV}_{1}$, there was a $20 \%$ increase in non-fatal coronary events and $28 \%$ increase in fatal coronary events among patients with mild-to-moderate COPD. However, other investigators reported that $\mathrm{FEV}_{1} \%$ was not significantly different between COPD patients with normal CIMT and those with a thickened CIMT (38).

Our data demonstrated that $\mathrm{PaO}_{2}$ was significantly lower, while $\mathrm{PaCO}_{2}$ was significantly higher, in COPD patients with a thickened CIMT compared those with a normal CIMT. These results suggest that COPD-related hypoxemia and/or hypercapnia are relevant factors for athero- sclerosis. Hypoxemia could lead to atherosclerosis through increasing systemic inflammation, oxidative stress, upregulating cell adhesion molecules, inducing hemodynamic stress, and increased foam cell production $(15,47,48)$. The same results were recorded by Ozbay et al. (36); they found that oxygen saturation was decreased in COPD patients with a thickened CIMT and reported that both intermittent and continuous hypoxemia resulted in remarkable alterations in CIMT.

In this study, logistic regression analysis demonstrated that age was a significant risk factor for a thickened intima and this might be explained by degenerative changes that occur with increasing age, including thickening of the vascular intima. This result is concordant with previous work that documents accelerated atherosclerosis of the arterial walls with age and various comorbid risk factors (9).

The limitation of this study was that the distributions of the groups according to smoking status and COPD stages were relatively heterogeneous.

\section{CONCLUSION}

Atherosclerosis was prevalent in about two-thirds (64\%) of COPD patients. A thickened CIMT was detected in the early stages of COPD patients and an insignificant difference was found between the mild-moderate to severe-very severe COPD patients. Factors contributing to atherosclerosis in COPD patients included: age, hypoxemia, hypercapnia, and COPD severity. Smoking status as not a contributing factor. Screening for atherosclerosis in COPD patients is recommended for starting early and proper management. Furthermore, interventional studies targeting atherosclerosis as well as studies to evaluate the effects of early oxygen therapy on CIMT in COPD patients are recommended.

Ethics Committee Approval: Ethics committee approval was received for this study from the ethics committee of Al-Azhar University, Cairo, Egypt.

Informed Consent: Written and verbal informed consent was obtained from patients who participated in this study.

Peer-review: Externally peer-reviewed.

Author Contributions: Concept - M.R.H., E.S., O.I.A., L.K.S.; Design - M.R.H., E.S., O.I.A., L.K.S.; Supervision - M.R.H., E.S., O.I.A., L.K.S.; Resources - M.R.H., E.S., O.I.A., L.K.S.; Materials - M.R.H., E.S., O.I.A., L.K.S.; Data Collection and/or Pro- 
cessing - M.R.H., E.S., O.I.A., L.K.S.; Analysis and/or Interpretation - M.R.H., E.S., O.I.A., L.K.S.; Literature Search - M.R.H., E.S., O.I.A., L.K.S.; Writing Manuscript M.R.H., E.S., O.I.A., L.K.S.; Critical Review - M.R.H., E.S., O.I.A., L.K.S.

Conflict of Interest: No conflict of interest was declared by the authors.

Financial Disclosure: The authors declared that this study has received no financial support.

\section{REFERENCES}

1. Bourdin A, Burgel PR, Chanez P, Garcia G, Perez T, Roche N. Recent advances in COPD: pathophysiology, respiratory physiology and clinical aspects, including comorbidities. Eur Respir Rev 2009; 18: 198-212. [CrossRef]

2. Maclay JD, MacNee W. Cardiovascular disease in COPD: mechanisms. Chest 2013; 143: 798-807. [CrossRef]

3. Lahousse L, van den Bouwhuijsen QJ, Loth DW, Joos GF, Hofman A, Witteman JC, et al. Chronic obstructive pulmonary disease and lipid core carotid artery plaques in the elderly: the Rotterdam Study. Am J Respir Crit Care Med 2013; 187: 58-64. [CrossRef]

4. Karakas OM, Cullu N, Karakas EK, Sak ZH, Yildizhan MU, Daglioglu E, et al. Evaluation of carotid intima-media thickness in the patients with chronic obstructive pulmonary disease. Acta Med Mediterr 2013; 29: 265.

5. Balta S, Demirkol S, Kucuk U, Arslan Z, Unlu M, Veliyev V. Carotid intima-media thickness is a relatively inexpensive and favorable prognostic marker in patients with spondyloarthritis. Sao Paulo Med J 2013; 131:436-8. [CrossRef]

6. Ogata T, Yasaka M, Yamagishi M, Seguchi O, Nagatsuka K, Minematsu $\mathrm{K}$. Atherosclerosis found on carotid ultrasonography is associated with atherosclerosis on coronary intravascular ultrasonography. J Ultrasound Med 2005; 24: 469-74.

7. Fimognari FL, Scarlata S, Conte ME, Incalzi RA, Fimognari FL, Scarlata S, et al. Mechanisms of atherothrombosis in chronic obstructive pulmonary disease. Int J Chron Obstruct Pulmon Dis 2008; 3: 89. [CrossRef]

8. Pobeha P, Skyba P, Joppa P, Kluchova Z, Szaboova E, Tkac I, et al. Carotid intima-media thickness in patients with chronic obstructive pulmonary disease. Bratisl Lek Listy 2011; 112: 24-8.

9. Lee HY, Oh BH. Aging and arterial stiffness. Circulation 2010; 74: 2257-62. [CrossRef]

10. Galal-Eldin M, Ahmad E, Hafez M, Sobh E, Alrayes M. Telomere length in chronic obstructive pulmonary disease. Egypt J Bronchol 2015; 9: 20.

11. Minamino $T$, Miyauchi $H$, Yoshida $T$, Ishida $Y$, Yoshida $H$, Komuro I. Endothelial cell senescence in human atherosclerosis role of telomere in endothelial dysfunction. Circulation 2002; 105: 1541-4. [CrossRef]

12. Benetos A, Okuda K, Lajemi M, Kimura M, Thomas F, Skurnick J, et al. Telomere length as an indicator of biological aging the gender effect and relation with pulse pressure and pulse wave velocity. Hypertension 2001;37:381-5. [CrossRef]

13. Maclay JD, Mcallister DA, Macnee W. Cardiovascular risk in chronic obstructive pulmonary disease. Respirology 2007; 12: 634-41. [CrossRef]

14. Invernizzi G. Persistence of systemic inflammation in COPD in spite of smoking cessation. Multidiscip Respir Med 2011; 6: 210-1. [CrossRef]

15. Savransky V, Nanayakkara A, Li J, Bevans S, Smith PL, Rodriguez A, et al. Chronic intermittent hypoxia induces atherosclerosis. Am J Respir Crit Care Med. 2007; 175: 1290-7. [CrossRef]

16. Maclay JD, McAllister DA, Mills NL, Paterson FP, Ludlam CA, Drost EM, et al. Vascular dysfunction in chronic obstructive pulmonary disease. Am J Respir Crit Care Med 2009; 180: 513-20. [CrossRef]

17. van Gestel YR, Flu WJ, van Kuijk JP, Hoeks SE, Bax JJ, Sin DD, et al. Association of COPD with carotid wall intima-media thickness in vascular surgery patients. Respir Med 2010; 104: 712-6. [CrossRef]

18. Simova I. Intima-media thickness: Appropriate evaluation and proper measurement, described. E-journal of the ESC Council for Cardiology Practice 2015; 13.

19. Jarauta E, Mateo-Gallego R, Bea A, Burillo E, Calmarza P, Civeira F. Carotid intima-media thickness in subjects with no cardiovascular risk factors. Rev Esp Cardiol 2010; 63: 97-102. [CrossRef]
20. GOLD. Global Strategy of Diagnosis, Management and Prevention of COPD; 2014. Available from: URL: http:/ www.goldcopd.org.

21. Miller MR, Crapo R, Hankinson J, Brusasco V, Burgos F, Casaburi R, et al. General considerations for lung function testing. Eur Respir J 2005; 26: 153-61. [CrossRef]

22. Rankin G, Stokes M. Reliability of assessment tools in rehabilitation: an illustration of appropriate statistical analyses. Clin Rehabil 1998; 12: 187-99. [CrossRef]

23. Martínez JM, Santos JM, Martínez ML, Pastor AM. Carotid intima-media thickness and hemodynamic parameters: reproducibility of manual measurements with Doppler ultrasound. Med Ultrason 2015; 17: 167-74. [CrossRef]

24. Schäberle W. Ultrasonography in vascular diagnosis: A therapy-oriented textbook and atlas. Springer Science \& Business Media; 2010 Dec 7.

25. Stein JH, Korcarz CE, Hurst RT, Lonn E, Kendall CB, Mohler ER, et al. American Society of Echocardiography Carotid Intima-Media Thickness Task Force. Use of carotid ultrasound to identify subclinical vascular disease and evaluate cardiovascular disease risk: a consensus statement from the American Society of Echocardiography Carotid Intima-Media Thickness Task Force. Endorsed by the Society for Vascular Medicine. J Am Soc Echocardiogr 2008; 21: 93-111. [CrossRef]

26. Onut R, Balanescu S, Constantinescu D, Calmac L, Marinescu M, Dorobantu M. Imaging Atherosclerosis by Carotid Intima-media Thickness in vivo: How to, Where and in Whom?. Maedica (Buchar) 2012; 7: 153-62.

27. Lorenz MW, Markus HS, Bots ML, Rosvall M, Sitzer M. Prediction of clinical cardiovascular events with carotid intima-media thickness a systematic review and meta-analysis. Circulation 2007; 115: 459-67. [CrossRef]

28. Bhatt SP, Dransfield MT. Chronic obstructive pulmonary disease and cardiovascular disease. Transl Res 2013; 162: 237-51. [CrossRef]

29. Mannino DM, Watt G, Hole D, Gillis C, Hart C, McConnachie A, et al. The natural history of chronic obstructive pulmonary disease. Eur Respir J 2006; 27: 627-43. [CrossRef]

30. Sabit R, Bolton CE, Edwards PH, Pettit RJ, Evans WD, McEniery CM, et al. Arterial stiffness and osteoporosis in chronic obstructive pulmonary disease. Am J Respir Crit Care Med 2007; 175: 1259-65. [CrossRef]

31. Vanfleteren L, Franssen F, Spruit MA, Groenen M, Roodt J, Rugman P, et al. Determinants of carotid intima-media thickness in patients with COPD: The Ciroco Study. Am J Respir Crit Care Med 2011; 183: A2608. [CrossRef]

32. Chindhi S, Thakur S, Sarkar M, Negi PC. Subclinical atherosclerotic vascular disease in chronic obstructive pulmonary disease: Prospective hospital-based case control study. Lung India 2015; 32: 137. [CrossRef]

33. Beşir FH, Yılmaz AL, Yazgan Ö, Dumlu T, Erkan ME, Önder E, et al. Evaluation of carotis intima media thickness in chronic obstructive pulmonary disease patients. Tuberk Toraks 2011; 60: 238-45.

34. Kim SJ, Yoon DW, Lee EJ, Hur GY, Jung KH, Lee SY, et al. Carotid atherosclerosis in patients with untreated chronic obstructive pulmonary disease. Int J Tuberc Lung Dis 2011; 15: 1265-70. [CrossRef]

35. Sadek SH, Hassan AA, AbdElrahman G, Kasem SM, AbdElwahed L, Eldein $\mathrm{HS}$, et al. Subclinical cardiovascular changes in chronic obstructive pulmonary disease patients: Doppler ultrasound evaluation. Egypt J Bronchol 2015; 9: 140. [CrossRef]

36. Ozbay B, Ozgokce M, Asker M, Asker S. Association of Intermittent and Continuous Hypoxaemia with Carotid and Brachial Arterial Intima-media Thicknesses. West Indian Med J 2016 Feb 12. pii: wimj.2015.370. doi: 10.7727/wimj.2015.370. [Epub ahead of print]. [CrossRef]

37. Arsovski Z, Gavrilovski M, Kaeva B, Busljetic K, Arsovska A. Carotid wall intima-media thickness (IMT) in COPD patients. Eur Respir J 2013; 42(Suppl 57): 3667.

38. Mills NL, Miller JJ, Anand A, Robinson SD, Frazer GA, Anderson D, et al. Increased arterial stiffness in patients with chronic obstructive pulmonary disease: a mechanism for increased cardiovascular risk. Thorax 2008; 63: 306-11. [CrossRef]

39. Alpaydin AO, Arslan IK, Serter S, Coskun AS, Celik P, Taneli F, et al. Metabolic syndrome and carotid intima-media thickness in chronic obstructive pulmonary disease. Multidiscip Respir Med 2013; 8: 1. [CrossRef]

40. Iwamoto H, Yokoyama A, Kitahara Y, Ishikawa N, Haruta Y, Yamane K, et al. Airflow limitation in smokers is associated with subclinical atherosclerosis. Am J Respir Crit Care Med 2009; 179: 35-40. [CrossRef] 
41. Barr RG, Ahmed FS, Carr JJ, Hoffman EA, Jiang R, Kawut SM, et al. Subclinical atherosclerosis, airflow obstruction and emphysema: the MESA Lung Study. Eur Respir J 2012; 39: 846-54. [CrossRef]

42. Schroeder EB, Welch VL, Evans GW, Heiss G. Impaired lung function and subclinical atherosclerosis: the ARIC study. Atherosclerosis 2005; 180: 367-73. [CrossRef]

43. Schroeder EB, Welch VL, Couper D, Nieto FJ, Liao D, Rosamond WD, et al. Lung function and incident coronary heart disease the atherosclerosis risk in communities study. Am J Epidemiol 2003; 158: 1171-81. [CrossRef]

44. Zureik M, Benetos A, Neukirch C, Courbon D, Bean K, Thomas F, et al. Reduced pulmonary function is associated with central arterial stiffness in men. Am J Respir Crit Care Med 2001; 164: 2181-5. [CrossRef]
45. Engström G, Hedblad B, Valind S, Janzon L. Asymptomatic leg and carotid atherosclerosis in smokers is related to degree of ventilatory capacity: longitudinal and cross-sectional results from 'Men born in 1914', Sweden. Atherosclerosis 2001; 155: 237-43. [CrossRef]

46. Anthonisen NR, Connett JE, Enright PL, Manfreda J. Hospitalizations and mortality in the Lung Health Study. Am J Respir Crit Care Med 2002; 166: 333-9. [CrossRef]

47. Lattimore JD, Wilcox I, Nakhla S, Langenfeld M, Jessup W, Celermajer DS Repetitive hypoxia increases lipid loading in human macrophages-a potentially atherogenic effect. Atherosclerosis 2005; 179: 255-9. [CrossRef]

48. Chen L, Einbinder E, Zhang Q, Hasday J, Balke CW, Scharf SM. Oxidative stress and left ventricular function with chronic intermittent hypoxia in rats. Am J Respir Crit Care Med 2005; 172: 915-20. [CrossRef] 